\title{
Ekstraksi Sederhana Antosianon dari Kulit Buah Naga (Hylocereus polyrhizus) sebagai Pewarna Alami
}

\section{Simple Extraction of Dragon Fruit (Hylocereus polyrhizus) Peel as Natural Dye Colorant}

\author{
Sri Sudarmi ${ }^{\mathrm{a}}$, Purwo Subagyo ${ }^{\mathrm{a}}$, Anna Susanti $^{\mathrm{a}^{*}}$, and Anggun Sri Wahyningsih ${ }^{\mathrm{a}}$ \\ ${ }^{a}$ Department of Chemical Engineering, Faculty of Industrial Technology, UPN “Veteran” Yogyakarta
}

Jl. SWK 104 Lingkar Utara Condongcatur Yogyakarta. 55283

\section{Artikel histori :}

Diterima: 20 Juni 2015

Diterima: dalam revisi 3 Juli 2015 Diterima: 7 Juli 2015 Online: 9 Juli 2015

\begin{abstract}
ABSTRAK: Pewarna alami dapat diperoleh dari pigmen yang berasal dari daun, buah, atau batang tanaman. Kulit buah naga adalah salah satu sumber pewarna alami yang berpotensi. Sekitar 30-35\% kulit buah dibuang sebagai sampah. Kulit buah naga mengandung warna kuning yang berasal dari pigmen antosianin yang berpotensi digunakan sebagai pewarna alami. Penelitian ini bertujuan mengetahui kondisi operasi optimum dari ekstraksi sederhana pengambilan antosianin. Operasi menggunakan 80\% ethanol dengan rasio bahan: solven (1:9 1:13). Suhu (50-80॰ C), dan waktu (1-5 jam). Hasil optimum diperoleh dari rasio 1:11, suhu $50{ }^{\circ} \mathrm{C}$, selama 3 jam.
\end{abstract}

Kata Kunci: Kulit buah naga; antosianin; pewarna alami; ekstraksi sederhana

\begin{abstract}
Natural dyes can be obtained from the pigments that contained from leaves, fruit, and rind of the plants. Dragon fruit peel is one of the potential natural pigment source. Almost $30-35 \%$ of the peel fruit is often simply thrown away as trash. Dragon fruit peel provides natural red color produced by pigment called anthocyanin which can be used as a subtituent from synthetic dyes to natural dyes. This research was objected to find the optimum conditions for anthocyanin extraction of dragon fruit peel. Simple extraction was carried out by using $80 \%$ ethanol solvent with variable ratio of the amount of material and solvent (1: 9 to $1: 13)$, temperature $\left(50^{\circ}\right.$ to $\left.80^{\circ} \mathrm{C}\right)$ and time ( 1 to 5 hours). Optimum result was obtained from a ratio F: $\mathrm{S} 1: 11$, temperature $50^{\circ} \mathrm{C}$, for 3 hours.
\end{abstract}

Keywords: Dragon fruit peel; anthocyanin; dye colorant; simple extraction

\section{Pendahuluan}

Zat warna banyak digunakan pada makanan, minuman, tekstil, kosmetik, peralatan rumah tangga dan industri. Saat ini, penggunaan pewarna sintetis begitu pesat digunakan pada makanan dan minuman. Dengan adanya penggunaan pewarna sintetis yang semakin marak, maka perlu adanya peningkatan dalam penggunaan pewarna alami. Salah satu sumber pigmen pewarna alami tersebut adalah kulit buah naga.

Beberapa penelitian tentang pemanfaatan kulit buah naga telah dilakukan. Vargas dkk (2013) mengekstrak pigmen antosianin dari kulit buah naga dengan ekstraksi maserasi menggunakan solven methanol asam. Sedangkan Kharidah dkk (2014) mengekstrak metoksil pektin dari kulit buah naga dengan metode ekstraksi ultrasound. Pada operaso penelitian sebelumnya masih sukar jika diaplikasikan untuk industry kecil dan menengah.
Kulit buah naga berpotensi sebagai pewarna alami makanan karena menghasilkan warna merah yang dihasilkan oleh pigmen yang bernama antosianin seperti cyanidin-3-sophoroside, dan cyanidin-3-glucoside (Wrolstad, 2000).

Antosianin adalah suatu kelas dari senyawa flavonoid secara luas terbagi dalam polifenol tumbuhan yang umumnya larut dalam air serta tersebar luas dalam bunga, kulit daun dan menghasilkan warna dari merah sampai biru (Winarno, 1992). Proses pemisahan digunakan untuk mendapatkan dua atau lebih produk yang lebih murni dari suatu campuran senyawa kimia. Ekstraksi adalah proses pemisahan suatu komponen dari campuran dua komponen atau lebih dimana komponen mengalami perpindahan massa dari suatu padatan atau cairan ke cairan lain yang bertindak sebagai pelarut (McCabe, 1990).

Proses ekstraksi sangat bergantung pada pemilihan pelarut yang sesuai sehingga akan mempengaruhi kelarutannya. Pelarut sebaiknya memiliki sifat-sifat

\footnotetext{
* Corresponding Author: +62274486889

Email: anna.susanti29@gmail.com
} 
diantaranya yaitu bersifat selektif, tidak terjadi reaksi antara pelarut dengan komponen yang akan diekstraksi, tidak korosif, mempunyai viskositas rendah dan daya pelarut tinggi, tidak beracun, mudah didapat dan murah (Houghton dan Rahman, 1998). Faktor-faktor yang mempengaruhi ekstraksi kulit buah naga diantaranya adalah suhu ekstraksi, waktu ekstraksi, ukuran bahan, perbandingan jumlah bahan terhadap pelarut dan pengadukan (Suwaji, 1979).

Penelitian ini bertujuan untuk menentukan kondisi optimum pada pengambilan zat warna (antosianin) dari kulit buah naga menggunakan cara ekstraksi sederhana dengan variabel perbandingan jumlah bahan terhadap pelarut, suhu ekstraksi dan waktu ekstraksi menggunakan pelarut etanol.

\section{Metode Penelitian}

\subsection{Bahan}

Bahan baku yang digunakan adalah kulit buah naga jenis daging merah yang diperoleh dari perkebunan buah naga 'Sabila Farm' Kalirurang Yogyakarta dan pelarut yang digunakan untuk tahap ekstraksi adalah etanol $80 \%$. Sedangkan untuk bahan pembantu yang dugunakan untuk tahap analisa kadar antosianin adalah larutan buffer KCL pH 1 dan larutan buffer $\mathrm{CH}_{3} \mathrm{COO}-\mathrm{Na} \mathrm{pH} 4,5$.

\subsection{Alat Penelitian}

Alat yang dipakai berupa labu leher tiga, pendingin balik, pengaduk merkuri, termometer, beaker glass, erlenmeyer, alat distilasi, spektrofotometer dan cuvet.

\subsection{Operasi Ekstraksi}

Variabel berubah dalam penelitian ini adalah perbandingan berat bahan dan pelarut (F:S) (1:9 1:10 1:11 $1: 12$ 1:13), suhu ekstraksi $(30,40,50,60,70 \circ \mathrm{C})$ dan waktu ekstraksi $(1,2,3,4$, dan 5 jam). Variabel tetap adalah konsentrasi pelarut, ukuran bahan, dan kecepatan pengadukan,

Kulit buah naga dipotong kecil-kecil kemudian dikeringkan dengan oven. Lalu dihaluskan menggunakan blender hingga berbentuk serbuk. Serbuk kulit buah naga diekstraksi menggunakan pelarut etanol 80\% kemudian hasil ekstraksi didistilasi untuk memisahkan ekstrak antosianin dengan pelarut etanol.

\subsection{Analisis Pewarna}

Distilat yang diperoleh diambil $1 \mathrm{ml}$ dan dimasukkan dalam labu ukur $10 \mathrm{ml}$, kemudian diencerkan dengan menggunakan larutan buffer KCL pH 1 sampai tanda batas. Kemudian diambil $1 \mathrm{ml}$ larutan hasil distilat dan dimasukkan dalam labu ukur $10 \mathrm{ml}$, lalu diencerkan dengan menggunakan larutan buffer $\mathrm{CH}_{3} \mathrm{COO}-\mathrm{Na} \mathrm{pH}$ 4,5 sampai tanda batas.

Absorbansi diukur tiap sampel pada $\lambda$ maks dan $\lambda 700$ nm. Distilat diuji absorbansinya dengan spektrofotometer UV-VIS pada panjang gelombang maksimum yaitu 520 $\mathrm{nm}$. Absorbansi dihitung dengan menggunakan persamaan 1 ,
$\mathrm{A}=\left(\lambda_{\text {maks }}-\lambda_{700}\right) \mathrm{pH} 1-\left(\lambda_{\text {maks }}-\lambda_{700}\right) \mathrm{pH} 4,5$

sedangkan kadar antosianin dihitung dengan persamaan 2 .

$\operatorname{Kadar} \operatorname{antosianin}(\mathrm{mg} / \mathrm{L})=\mathrm{A} \times \mathrm{BM} \times \mathrm{FP} \times 1000 / \varepsilon$

\section{Keterangan}

- $\varepsilon=$ koefisien absorbivitas $26900 \mathrm{~L} / \mathrm{mol}_{\mathrm{cm}} \mathrm{cm}^{-1}$ dinyatakan sebagai cyanidin-3-glucoside

- $\mathrm{BM}=$ berat molekul cyanidin-3- glucoside (449.2 $\mathrm{g} / \mathrm{mol}$ )

- $\quad \mathrm{FP}=$ faktor pengenceran

- $\quad \lambda_{\text {maks }}=\operatorname{serapan}$ maksium sampel $(520 \mathrm{~nm})$

- $\quad \lambda_{700}=$ serapan cyanidin-3- glucoside

(Wrolstad dan Giusti, 2001)

\section{Hasil dan Pembahasan}

\subsection{Hubungan Berat Bahan dan Pelarut terhadap Antosianin}

Gambar 1 menunjukkan bahwa semakin besar jumlah pelarut yang digunakan maka jumlah antosianin yang terambil semakin banyak. Pada perbandingan berat bahan dan pelarut dengan $\mathrm{F}: \mathrm{S}$ yaitu 1:9 sampai 1:11 mengalami kenaikan kadar antosianin. Hal ini disebabkan karena semakin besar jumlah pelarut maka kontak antara pelarut dengan bahan padat menjadi sempurna sehingga antosianin yang terlarut semakin banyak.

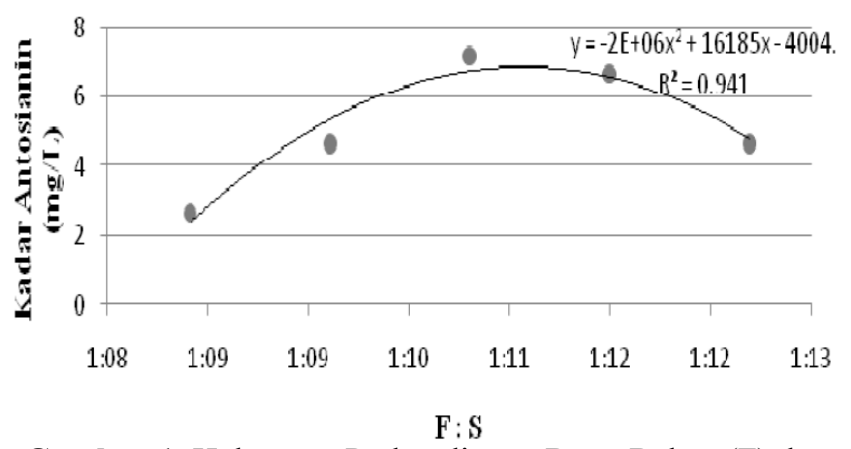

Gambar 1. Hubungan Perbandingan Berat Bahan (F) dan Solven (S) terhadap Antosianin

Namun, pada perbandingan berat bahan dan pelarut mulai dari F:S yaitu 1:12 dan 1:13 mengalami penurunan kadar antosianin karena volume pelarut yang digunakan telah melebihi dari titik maksimumnya sehingga tidak dapat memberikan efek kenaikan kadar antosianin. Sehingga pada perbandingan 1:11 merupakan kondisi terbaik maka pelarut dapat larut dengan baik ke dalam bahan.

\subsection{Suhu Ekstraksi}

Gambar 2 menunjukkan bahwa semakin tinggi suhu ekstraksi maka jumlah antosianin yang terlarut semakin besar. Pada suhu $30{ }^{\circ} \mathrm{C}$ sampai $50{ }^{\circ} \mathrm{C}$ kadar antosianin yang terambil semakin banyak karena semakin tinggi suhu ekstraksi maka kelarutan semakin meningkat. 
Akan tetapi, hal ini tidak berlaku pada suhu diatas $50{ }^{\circ} \mathrm{C}$ yang mengalami penurunan kadar antosianin karena pada suhu diatas $50^{\circ} \mathrm{C}$ merupakan suhu diatas kestabilan antosianin, maka sebagian antosianin mengalami degradasi karena panas. Degradasi antosianin disebabkan oleh hidrolisis pada ikatan glikosidik antosianin dan menghasilkan aglikon-aglikon yang labil. Oleh karena itu, pada suhu $60^{\circ} \mathrm{C}$ dan $70^{\circ} \mathrm{C}$ kadar antosianin yang terambil semakin menurun. Sehingga pada suhu $50^{\circ} \mathrm{C}$ merupakan suhu yang relatif baik dalam penelitian ini.

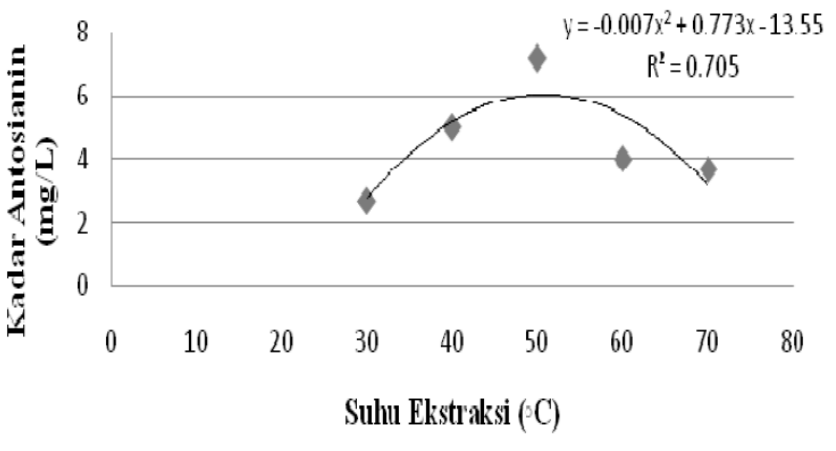

Gambar 2. Hubungan Suhu Ekstraksi dan Kadar Antosianin

\subsection{Waktu Ekstraksi}

Gambar 3 menunjukkan bahwa pada semakin lama waktu ekstraksi maka kadar antosianin akan semakin banyak. Hal ini disebabkan karena semakin lama waktu ekstraksi maka waktu kontak antara bahan dan pelarut semakin lama sehingga semakin banyak antosianin yang terlarut di dalamnya. Namun pada waktu ekstraksi lebih dari 3 jam, kadar antosianin mengalami penurunan yang cukup signifikan.

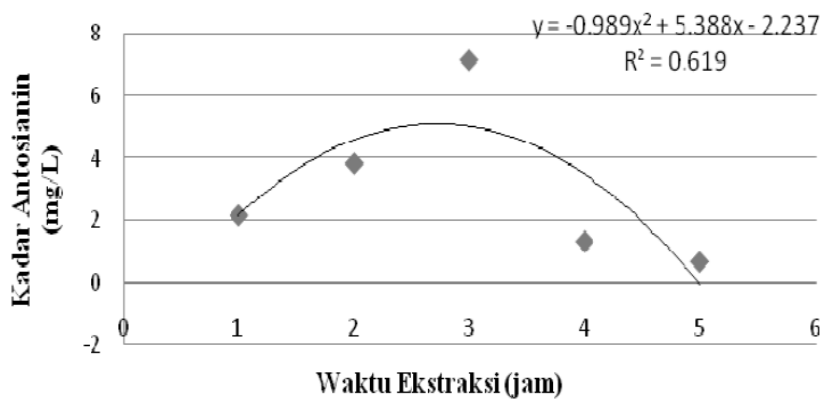

Gambar 3. Hubungan Waktu Ekstraksi dan Kadar Antosianin

Hal ini disebabkan karena, semakin lama waktu pengadukan mengakibatkan semakin lamanya juga waktu pemanasan sehingga mengakibatkan semakin kecil kadar antosianin di dalam pelarut (jumlah antosianin yang diperoleh semakin sedikit). Hal ini diduga dengan semakin lamanya waktu pemanasan maka akan mengakibatkan pigmen antosianin mengalami degradasi. Lamanya waktu pemanasan menyebabkan terjadinya degradasi (dekomposisi) dan perubahan struktur pigmen sehingga terjadi pemucatan. Untuk itulah, waktu ekstraksi selama 3 jam merupakan waktu yang relatif baik yang didapat dalam penelitian ini.

\section{Kesimpulan}

Pengambilan antosianin dari kulit buah naga dapat dilakukan dengan cara ekstraksi menggunakan pelarut etanol. Dari penelitian ini diperoleh kondisi optimum ekstraksi kulit buah naga dengan menggunakan pelarut etanol yaitu pada perbandingan $\mathrm{F}: \mathrm{S}$ sebesar $1: 11$ pada suhu $50{ }^{\circ} \mathrm{C}$ dengan waktu ekstraksi 3 jam dan kadar antosianin yang dihasilkan sebanyak 7,180 mg/L.

\section{Ucapan Terima Kasih}

Puji dan syukur kami panjatkan kepada Allah SWT atas segala nikmat dan ridho-Nya. Terima kasih kami sampaikan kepada seluruh pihak yang telah membantu dalam pelaksanaan penelitian ini serta memberikan pengarahan, saran dan kritik yang membangun hingga laporan penelitian ini dapat diselesaikan.

\section{Daftar Pustaka}

Houghton, Peter J. \& A. Rahman. 1998. Laboratory Handbook for the Fractination of Natural Extract. Chapman and Hall : London.

Kharidah Muhammad, Nur Izalin Mohd. Zahari, Sri Puvanesvari Gannasin, Noranizan Mohd. Adzahan, Jamilah Bakar, 2014. High methoxyl pectin from dragon fruit (Hylocereus polyrhizus) peel. Food Hydrocolloids, 42, (2): 289-297.

McCabe,W.L., 1990. Unit Operation Of Chemical Engineering $\mathrm{X}^{\text {th }}$ edition. Mc Graw Hill Book Company, New York.

M. Vargas, J. Cortez, E. Duch, A. Lizama and C. Méndez, 2013. Extraction and Stability of Anthocyanins Present in the Skin of the Dragon Fruit (Hylocereus undatus), Food and Nutrition Sciences. 4 (12): 12211228.

Suwaji, dkk., 1979. Laporan Penelitian Tentang Pemanfaatan Sumber Nabati Sebagai Pewarna dalam Industri Makanan dan Minuman. Balai Penelitian, Semarang.

Winarno, F.G.,1992, Kimia Pangan dan Gizi. PT Gramedia, Jakarta.

Worlstad, R.E., 2000. Anthocyanins Natural Food Colorants, Science and Technology, Marcel Dekker, New York.

Wrolstad, R. E. and Giusti, M. M., 2001, Characterization and Measurement of Anthocyanin by UV-Visible Spectroscopy: Current Protocols in Food Analytical Chemistry, John Wiley and Son, New York. 